
\title{
25 Research Square \\ Importance of Water Level Management for Peatland Outflow Water Quality in the Face of Climate Change and Drought
}

Shokoufeh Salimi

Lunds Universitet

Miklas Scholz ( $\square$ miklas.scholz@tvrl.lth.se)

Lunds Universitet https://orcid.org/0000-0001-8919-3838

\section{Research Article}

Keywords: Bog, Dissolved organic carbon, Ecosystem collapse, Global warming, Nitrogen, Nutrient release, Peat decomposition, Phosphorus

Posted Date: January 25th, 2022

DOI: https://doi.org/10.21203/rs.3.rs-1189645/v1

License: (c) (1) This work is licensed under a Creative Commons Attribution 4.0 International License. Read Full License 


\section{Abstract}

The impact of different climate scenarios, drought, and water level management on the outflow water quality of peatlands has been investigated. A mesocosm experiment has been conducted within climate control chambers to simulate current (2016-2019 real-time) and future representative concentration pathway (RCP) climate scenarios (RCP 2.6, 4.5 and 8.5) for the peatland mesocosms. To assess the efficiency of a management strategy for improving peatland water quality, water level adjustment was applied to half of the system at the same time for each climate scenario. Furthermore, the mesocosm experienced the 2018 European drought during the simulation years, and the corresponding impact was analyzed. The results of this study indicated that the effect of water level but not climate change on the water quality of peatland mesocosms was significant. The effect of water level management was the largest for ammonium $\left(\mathrm{NH}_{4}-\mathrm{N}\right)$ and five-day biochemical oxygen demand $\left(\mathrm{BOD}_{5}\right)$, and the smallest for total phosphorus (TP). Drought had a strong impact on chemical variables, increasing their concentration and deteriorating the water quality of peatland outflow. The results highlight the need for water level management in stabilizing nutrient levels in peatland outflows, especially for the warmer climate scenarios to mitigate the negative consequences of global warming.

\section{Introduction}

Peatlands are unique ecosystems that cover around $3 \%$ of the global land surface and are one of the most vulnerable ecosystems to climate change (Harenda et al. 2018). Peatlands, like other wetland ecosystems, serve as a transitional zone where terrestrial and aquatic environments collide. Therefore, any kind of peatland disturbance such as a collapse of parts of the ecosystem has an impact on the aquatic ecosystem. Peatlands can be considered as storage systems of carbon in the landscape (Bragazza et al. 2013). They have the ability to accumulate dead organic matter (transformed into peat over time) when the rate of plant litter generation exceeds the rate of peat degradation, which occurs under prevailing waterlogging conditions (Limpens et al. 2008). One of the most unique and valuable services of a pristine peatland is retention of carbon and nutrients and prevention of erosion, delivering improved water quality to downstream regions (Ritson et al. 2016; Tuukkanen et al. 2017).

The high moisture retention capacity of a peatland is regarded as a crucial regulator of this ecosystem increasing its resilience to any disturbances (Waddington et al. 2015). Climate events such as droughts are expected to become more common as a result of climate change-related alternations in temperature and precipitation (Erwin 2019). This might have direct and indirect consequences on peatland functionality in the catchment. Less water availability as a result of a higher rate of evapotranspiration under climate change and drought might cause an aerobic decomposition of peat and release of stored nutrients and pollution into the peatland outflow, harming the downstream water quality (Macrae et al. 2013; Juckers and Watmough 2014; Tuukkanen 2017). Moreover, factors that contribute to peatland degradation, such as severe droughts, not only accelerate the rate of organic matter decomposition but also increase the amount of carbon dioxide $\left(\mathrm{CO}_{2}\right)$ emission into the atmosphere (Lucchese et al., 2010, Grover and Baldock 2013, Jassey et al. 2018).

The high moisture retention capacity of peatlands is recognized as a critical regulator of peatland functions. Nonetheless, studies revealed that the best function of peatlands depend on careful water level management, keeping the water level within specified limits to prevent them from becoming overly wet or too dry (Macrae et al. 
2013, Menberu et al. 2017). This is critical for preserving peatland ecosystem services including flood and nutrient retention, carbon sequestration and biodiversity.

The complexity of the response of the peatland ecosystem might be attributed to some degree to the fact that the vegetation composition would shift gradually as a result of climate change, and this shift may modify nutrient demands and potential uptake by the vegetation (Turetsky 2003). As a result, while the warmer climate and lower water level would promote peat degradation and nutrient release (Belyea et al. 2004; Strack et al. 2008; Macrae et al. 2013) the altered plant composition could increase nutrient uptake and offset the adverse implications of warmer climate on peatland ecosystems to some extent (Salimi and Scholz 2021). Other studies, however, have found that biomass nutrient pools might remain significantly smaller than soil pools indicating (Westman and Laiho 2003) the dominance of mineralization over immobilization raising concerns about organic compounds and nutrients leaching from peatlands.

Providing a stable hydrologic regime for the peatland supports the dominance of the key plant Sphagnum moss, which protects the bog from being readily degraded, retaining the carbon storage of the peatland. In contrast, higher water table fluctuations as a result of climate change are anticipated to change the plant and microbial community affecting nutrient mineralization patterns and carbon cycling. Predicting the extent and direction of the response of peatland water quality to climate change and drought is challenging (Moore et al. 1998). Since the literature contains contradictory results regarding the impact of water table changes on nutrient release (Tiemeyer et al. 2007; Urbanová et al. 2011; Macrae et al. 2013), understanding the water level management effect on water quality is critical. Moreover, as various climate scenarios might demand different types of management including water level adjustment, the assessment of different management strategies for different climate scenarios is therefore necessary.

An on-going mesocosm experiment has been started in 2017. The authors investigate the impact of climate change and water level management on peatland (ombrotrophic bog) ecosystems. This study is unique in that it is the first time a dynamic simulation of current and future RCP climate scenarios has been conducted within climate control chambers for peatlands allowing for a close understanding of changes in the peatland ecosystem (Salimi et al. 2021). Furthermore, water level management was undertaken concurrently to understand the efficiency of this management action for all simulated climate scenarios (Salimi et al. 2021). The simulated climate scenarios were based on real-time data for 2017, 2018 and 2019. Although 2017 was considered a year with regular rain during the warm season, 2018 was recorded as the warmest and driest summer since 1950, and 2019 had the second warmest summer since 1950, but fairly typical precipitation.

The main objectives of this research were to (a) investigate the impact of different climate scenarios on peatland water quality; (b) assess the effect of drought on peatland degradation; and (c) evaluate the impact of water level management on peatland water quality under different climate scenarios.

\section{Materials And Methods}

\section{Sampling of peatland for mesocosm experiments}

Peatland samples were extracted from Fäjemyr, which is an ombrotrophic bog in the province of Scania (latitude $5615^{\prime} \mathrm{N}$, longitude 1333' $\mathrm{E}$ and altitude of $140 \mathrm{~m}$ ). The samples were collected from the top layer of the peatland and deposited directly in tanks $(30 \mathrm{~cm}$ in length, $22 \mathrm{~cm}$ in width and $24 \mathrm{~cm}$ in height) during fieldwork. The 
peatland mesocosms are made-up of $20 \mathrm{~cm}$ of top bog plants with some young peat at the bottom. Fäjemyr vegetation is dominated by dwarf shrubs (Calluna vulgaris and Erica tetralix), sedges (Eriophorum vaginatum) and Sphagnum spp. (S. magellanicum and S. rubellum) (Lund et al. 2012). All mesocosms were built to be indicative of the site, with relatively similar proportions of dominant plant types.

\section{Climate scenario creations for subsequent simulations}

In this study, the scenarios called representative concentration pathway (RCP) were used for creating future climate scenarios for the climate chambers. These RCP future climate scenarios are based on different radiative forcing target levels for the future and were provided by the Intergovernmental Panel on Climate Change (IPCC) (AR5; IPCC, 2007). According to the IPCC's Fifth Assessment Report (AR5; IPCC, 2007), there are four possible scenarios: RCP 2.6, RCP 4.5, RCP 6 and RCP 8.5 (Van Vuuren et al. 2011). Three RCP climate scenarios (RCP 2.6, RCP 4.5 and RCP 8.5) were used to simulate low, moderate and extreme future climate change scenarios in the corresponding climate chambers.

Table S1, which is located in the online resource linked to this article, lists the regional RCM, which have been used for the simulation of future scenarios. Hourly data of the different climate variables temperature, precipitation, relative humidity and radiation for the regional climate models (RCM) for various RCP scenarios were collected from the Rossby Centre of the Swedish Meteorological and Hydrological Institute (SMHI). There were five RCM datasets available at SMHI for RCP 4.5 and 8.5, and 10 RCM datasets for RCP 2.6, 4.5 and 8.5 (Giorgi et al. 2015, Jacob et al. 2014). The data were collected for the domain of Scania County located in southern Sweden.

Since all RCM outputs are uncertain, no single RCM was used to create the climate scenarios, instead, the delta change technique was used to include all existing RCM to reduce uncertainty. In this method, the difference between the output of each RCM for the last 30 years of the century $(2069 k-2098)$ and the historical data of the same models for the same number of years (1976-2005) has been estimated. The results were then averaged across all RCM models for all RCP, and, subsequently, the estimated differences (for temperature) and ratios (for precipitation, relative humidity and radiation) were calculated for each month resulting in monthly delta change coefficients. Finally, the calculated monthly delta change coefficients were applied to the hourly observation data of Malmö station (2016-2019 climate data from Malmö A and Lund station, which has been considered as current climate data) and the future climate variables were created.

\section{Advanced climate chambers}

The authors employed four advanced climate chambers KK 750 (Pol-Eko-Aparatura Wodzisaw SIski, Poland; https://www.pol eko.com.pl/model/climatic-chambers-kk/climatic-chamber-kk-750/) to simulate the climate scenarios. The climate chambers are remotely programmable allowing the user to regulate the temperature and relative humidity, as well as radiation at a resolution of three hours (Fig. 1). However, precipitation simulation was conducted manually on a weekly basis. To ensure a realistic and dynamic simulation, all four climatic variables were simulated continuously throughout the year, with no gaps during the cold season (Salimi et al. 2021).

The climate chambers are equipped with a phytotron system to regulate temperature and humidity. Moreover, to simulate day and night, each climate chamber is supplied with an 840 (daylight) fluorescent lamp. The climate chamber is able to control the intensity and duration of the illumination. The chamber regulates the temperature from $-10^{\circ} \mathrm{C}$ to $+60^{\circ} \mathrm{C}$ with the light switched-off, and from $0^{\circ} \mathrm{C}$ to $+50^{\circ} \mathrm{C}$ with the light on. Each climate chamber 
has an ultrasonic humidifier that has been connected to the deionized water system to provide the chamber with the desired humidity level. An air flap and a ventilator were also installed to ensure that air extraction and circulation are consistent.

\section{Design of the mesocosm experiment}

Four advanced climate chambers were employed to simulate four different climate scenarios including the current climate scenario as a control, and three future RCP climate scenarios. Sixteen peatland mesocosms were randomly distributed into four climate chambers, each with four peatland mesocosms (Fig. 1). Four mesocosms in each climate chamber were divided into managed and unmanaged groups (two replicates for each group) to understand how changes in water level might affect the water quality of peatland outflow under different climate scenarios (Fig. 1). The water levels in the managed mesocosms were regulated, but not in the unmanaged ones (see section 2.5).

\section{Water level management}

Precipitation was simulated weekly for all mesocosms in all chambers using precipitation data from the generated climate scenarios explained above. Rainwater was collected from nearby greenhouse glass roofs and manually applied to the mesocosm top surface, where it infiltrates into the peatland soil, and eventually is released into the standing pipe located in the center of each mesocosm. The water level in the mesocosms was regulated for two managed replicates to be comparable to the unmanaged ones in terms of water quality. The water levels between $10( \pm 0.5)$ and $18( \pm 0.5) \mathrm{cm}$ (from the bottom of the tank) were considered as acceptable thresholds for mesocosms to provide all plants with water for photosynthesis. Water level management was accomplished either by adding water from the nearby real storm water pond called Lake Lake (Sjön Sjön in Swedish), which is located on the campus of the Faculty of Engineering at Lund University, to the mesocosms when the water level dropped to less than $10 \mathrm{~cm}$ due to evapotranspiration or by removing excess water (runoff or management outflow) from the mesocosms when the water level exceeded $18 \mathrm{~cm}$. Water was added for management purposes to the top surface of the mesocosms, while excess water was removed from the vertical standing pipe positioned in the center of each mesocosm where in practice the mesocosm outflow would be collected via a belowground horizontal collection pipe system. Water level adjustment was not performed for the unmanaged mesocosms. Therefore, rainwater was the only inflow to the unmanaged mesocosms. Therefore, some mesocosms encountered extreme events such as droughts and floods (maximum $4 \mathrm{~cm}$ above the topsoil).

\section{Physiochemical parameter measurements}

Important physiochemical variables were identified and measured to understand how the water quality in managed and unmanaged peatland mesocosms might change over time under different climate scenarios. Salimi and Scholz (2021) provided an explanation for the selection of physiochemical variables. Different nutrient-related parameters including ammonium, total phosphorus as well as dissolved organic carbon (DOC), chemical oxygen demand (COD), $\mathrm{BOD}_{5}$ and $\mathrm{pH}$ were measured. This study also examined physical water quality indices such as dissolved oxygen (DO) and total suspended solids (TSS).

Dissolved organic carbon (DOC) was analyzed using the TOC analyzer TOC-V CPH-TNM-1 (Shimadzu). The BOD 5 was measured using the OxiTop Control System OC 110® (WTW, Germany). Total phosphorus (TP) was analyzed using the inductively coupled plasma atomic emission spectrometry (ICP-OES) Optima 8300, (Perkin Elmer ELAN 6100, Perkin Elmer Inc., Waltham, Mass) in accordance with the USEPA method 200.7 (USEPA 1994). 
Furthermore, ammonium-nitrogen $\left(\mathrm{NH}_{4}-\mathrm{N}\right)$ was monitored in this study and determined by flow injection analysis (FIA) using a FIAstar 5000 Analyzer (Foss Tecator, Höganäs, Sweden) according to ISO 11732:2005 and ISO 11732, respectively. Dissolved oxygen was measured directly from the mesocosms outflow pipe, along with other variables each month. Total suspended solids were determined using Lovibond MD 100 (VWR, Germany). The pH was measured with the $\left(\mathrm{pH} / \mathrm{mV} /{ }^{\circ} \mathrm{C}\right.$ meter pHenomenal ${ }^{\circledR} \mathrm{pH} 1100 \mathrm{~L}$ meter (VWR, Germany).

\section{Statistical Analyses}

The effects of the main factors water level management and climate scenario as well as their interactions impacting on physicochemical parameters change over time and were evaluated using a two-way repeated measures multivariate analysis of variance (RM-MANOVA). The sampling month (time) was included as a withinsubject to enable for treatment effects to be evaluated despite seasonal fluctuations of the dependent variables. Water table management and climate scenarios were considered as the between-subject factors.

To obtain a sufficient sample size in relation to the number of dependent variables, the physiochemical parameters were grouped into fewer chemical and physical parameters. Moreover, the potential autocorrelations between dependent variables were considered in the analysis. In RM-MANOVA, Wilk's Lambda was used to determine the significance of the main factors. The RM-MANOVA effect sizes were examined using partial eta squared (p2). The Bonferroni adjustment test was used to determine pairwise differences. For all tests, the significance level was set at $p<0.05$.

\section{Results}

\section{Comparisons of environmental variables under different climate scenarios}

Additional findings related to simulated climate variables are shown in the online resource linked to this article (Figs. S1 and S2). A comparison of temperature means (Tukey's test) for different climate scenarios revealed that all climate scenarios were significantly different (Tukey's test; $p<0.05$ ) from one another (Fig. S1b). From the current climate, there was an increasing trend towards RCP 8.5. The differences between the annual average temperature of the future climate scenarios RCP 2.6, RCP 4.5 and RCP 8.5 relative to the current climate (control scenario) were $1.8 \pm 0.52^{\circ} \mathrm{C}, 2 \pm 0.43^{\circ} \mathrm{C}$ and $3.2 \pm 0.75^{\circ} \mathrm{C}$, respectively (Fig. S2b)

There was no significant difference in relative humidity $(p>0.05)$ between the current climate scenario and RCP 2.6, nor between RCP 4.5 and RCP 8.5. However, the current climate scenario and RCP 2.6 had significantly lower relative humidity values ( $p<0.05$ ) than RCP 4.5 and RCP 8.5 (Fig. S1c). Furthermore, precipitation increased from the current climate scenario to RCP 8.5 , but there was no significant difference $(p>0.05)$ among the four climate scenarios (Fig. S1d).

Radiation showed a declining trend from the coldest (current) climatic scenario to the warmest (RCP 8.5) according to Fig. S1a. RCP 4.5 and RCP 8.5 had significantly higher radiation than the current climate, but not RCP 2.6. Furthermore, no significant differences in radiation were found across all future temperature scenarios (Fig. S1a). 
The averages of the water levels for the current climate, RCP 2.6, RCP 4.5 and RCP 8.5 scenarios for the unmanaged replicates were $11.6 \pm 7.10,10.4 \pm 7.20,11.0 \pm 6.95$ and $12.6 \pm 6.53$ and for the managed replicates were $12.0 \pm 3.26,12.6 \pm 3.09,13.5 \pm 3.2$ and $13.3 \pm 3.27$ over three years of the experimental period 2017-2020.

\section{Effect of climate scenario and water level management on physiochemical variables}

Figure 2 shows the two-year averages of selected water quality variables. The significance test is based on a pairwise comparison followed by RM-MANOVA. The latter results revealed that the main factor (climate scenario) had no statistically significant impact on any group of variables: (a) DOC, COD and TSS ( $p=0.29$, Wilks' Lambda $\left.=0.23, \eta_{p}^{2}=0.39\right)$; (b) $\mathrm{NH}_{4}-\mathrm{N}$, TP and BOD 5 ( $\mathrm{p}=0.40$, Wilks' Lambda $\left.=0.11, \eta_{\mathrm{p}}{ }^{2}=0.52\right)$; and (c) DO and pH ( $\mathrm{p}=$ 0.17 , Wilks' Lambda $\left.=0.21, \eta_{p}{ }^{2}=0.54\right)$. However, the effect of water level management was found to be statistically significant for all groups of variables: (a) DOC, COD and TSS ( $p=0.002$, Wilks' Lambda $=0.10, \eta_{p}{ }^{2}=$ 0.90); (b) $\mathrm{NH}_{4}-\mathrm{N}$, TP and BOD 5 ( $p=0.002$, Wilks' Lambda $\left.=0.01, \eta_{p}{ }^{2}=0.99\right)$; and (c) $\mathrm{DO}$ and $\mathrm{pH}(\mathrm{p}=0.03, \mathrm{Wilks}$ Lambda $\left.=0.25, \eta_{p}^{2}=0.76\right)$.

The interaction effect of climate scenario and water level management was not statistically significant for any groups of variables: (a) DOC, COD and TSS ( $p=0.33$, Wilks' Lambda $=0.25, \eta_{p}^{2}=0.37$ ); (b) $\mathrm{NH}_{4}-\mathrm{N}^{2} \mathrm{TP}^{2}$ and BOD $\left(p=0.32\right.$, Wilks' Lambda $\left.=0.09, \eta_{p}^{2}=0.56\right)$; and $(c)$ DO and $\mathrm{pH}\left(p=0.21\right.$, Wilks' Lambda $\left.=0.24, \eta_{p}{ }^{2}=0.52\right)$. The results showed no statistically significant differences $(p>0.05)$ between the mean values of any physiochemical variables for different climate scenarios concerning both managed and unmanaged mesocosms, with the exception of TSS, which showed a significant difference between RCP 8.5 and CC for the unmanaged system (Fig. 2f). In terms of the mean values of TP and DO, no significant difference was identified between the managed and unmanaged systems at any level of climate scenario (Fig. 2a,d). A pairwise comparison showed significant differences between the COD and TSS mean values of managed and unmanaged systems under all future climate scenarios (Fig. 2g,f). However, for the current climate, there was no significant difference between the COD and TSS mean values of managed and unmanaged mesocosms (Fig. $2 g, f$ ).

The $\mathrm{NH}_{4}-\mathrm{N}$ mean values of unmanaged systems were significantly higher than the ones for the managed systems under all climate scenarios (Fig. 2c). Unexpectedly, only RCP 8.5 revealed a significant difference between the DOC mean value of the managed and unmanaged mesocosms, but not the other climate scenarios (Fig. 2e). The mean $\mathrm{BOD}_{5}$ concentrations of the unmanaged mesocosms under all climate scenarios was significantly higher than the managed ones, except under RCP 4.5 (Fig. 2h). For all climate scenarios, except for RCP 2.6, the mean pH levels in the unmanaged mesocosms were significantly higher than those for the managed ones (Fig. 2b).

Figure 3 shows the trends of selected parameters for peatland mesocosms under different climate scenarios over a three-year experimental period. The water quality deteriorated considerably in replicates 1 and 2 over time, where the water level was regulated during the first year of the experiment (2017-2018), but left unmanaged in subsequent years (2018-2020). For all climate scenarios, except for the current climate, the mean values of $\mathrm{NH}_{4}$ $\mathrm{N}, \mathrm{DOC}$ and COD as well as the concentrations of the replicates 1 and 2 for the period 2019-2020 were significantly higher compared to the periods 2017-2018 and 2018-2019 (Fig. 3c,e,g). However, there was no statistically significant difference between the periods 2017-2018 and 2018-2019 for these variables 
concerning all climate scenarios (Fig. 3c,e,g). The average TP, DO, TSS and BOD 5 values for the replicates 1 and 2 did not differ significantly over the years (Fig. 3a,d,f, h). The pH was elevated in both managed and unmanaged mesocosms for all climate scenarios over time (Fig. 3b). Under all climate scenarios, the pH values of the replicates 1 and 2 for the period 2019-2020 were significantly higher than for the 2017-2018 and 2018-2019 periods, with the exception of the current climate (Fig. 3b).

The water quality remained relatively stable or improved for the replicates 3 and 4 (managed throughout the whole experimental period) as most physiochemical variables decreased or remained relatively constant (Fig. 3). For example, there were no significant differences in the mean TP, DO and COD concentrations for the replicates 3 and 4 between the years of the experiment (Fig. 3a,d,g).

The mean DOC concentrations for the replicates 3 and 4 under RCP 8.5 were significantly greater for the period 2017-2018 than for 2018-2019 (Fig. 3e). Furthermore, under RCP 8.5, the mean $\mathrm{NH}_{4}-\mathrm{N}_{\text {concentrations for the }}$ replicates 3 and 4 were significantly lower for the period 2019-2020 than for both 2017-2018 and 2018-2019 (Fig. 3c). For all climate scenarios, the mean $\mathrm{BOD}_{5}$ of the replicates 3 and 4 for the period 2017-2018 was shown to be significantly higher than for 2019-2020 and for RCP 8.5. All annual data were significantly different from each other (Fig. 3h). The mean TSS of replicates 3 and 4 for the period 2017-2018 was significantly higher than for both 2018-2019 and 2019-2020 under the current climate scenario. However, under RCP 2.6, all years were significantly different from one another. Moreover, there was no significant difference between the years under RCP 4.5 and RCP 8.5 (Fig. 3f).

The results of the two-way RM-MANOVA indicated that the effect of climate scenario is only significant for DO among all other assessed physiochemical variables (Table 1). The effect of water level management on the other hand was shown to be significant for all physiochemical variables except for TP and DO (Table 1). The greatest impact of water level management was for $\mathrm{NH}_{4}-\mathrm{N}$ and $\mathrm{BOD}_{5}$ with the smallest being for DO (Table 1). The interactive effect of water level management and climate scenario was found to be significant only for TSS, but not for any other examined variables in this study (Table 1). 
Table 1

Results of the two-way repeated measures multivariate analysis of variance (RM-MANOVA) representing the effect of the main factors climate scenario, management and their interactions (climate scenario*management) on the physicochemical variables

\begin{tabular}{|c|c|c|c|c|c|c|c|c|c|c|c|c|}
\hline \multirow[t]{2}{*}{$\begin{array}{l}\text { Variable } \\
\text { (factor) }\end{array}$} & \multicolumn{4}{|c|}{ Climate scenario } & \multicolumn{4}{|c|}{ Management } & \multicolumn{4}{|c|}{$\begin{array}{l}\text { Climate } \\
\text { scenario*management }\end{array}$} \\
\hline & df & $F$ & $\mathbf{P}$ & $\eta_{p}^{2}$ & df & $F$ & $\mathbf{P}$ & $\eta_{p}^{2}$ & df & $F$ & $\mathbf{P}$ & $\eta_{p}^{2}$ \\
\hline TPa & 3 & 1.44 & 0.336 & 0.46 & 1 & 2.76 & 0.158 & 0.37 & 3 & 0.38 & 0.771 & 0.19 \\
\hline $\mathrm{NH}_{4}-\mathrm{N}^{\mathrm{b}}$ & 3 & 1.00 & 0.467 & 0.37 & 1 & 97.19 & $<0.001$ & 0.95 & 3 & 1.60 & 0.300 & 0.49 \\
\hline $\mathrm{DOC}^{\mathrm{C}}$ & 3 & 1.85 & 0.22 & 0.41 & 1 & 20.28 & 0.002 & 0.72 & 3 & 0.73 & 0.564 & 0.21 \\
\hline $\operatorname{COD}^{d}$ & 3 & 1.45 & 0.30 & 0.35 & 1 & 47.38 & $<0.001$ & 0.86 & 3 & 2.12 & 0.176 & 0.44 \\
\hline $\mathrm{BOD}_{5}{ }^{\mathrm{e}}$ & 3 & 2.44 & 0.180 & 0.59 & 1 & 87.64 & $<0.001$ & 0.95 & 3 & 4.82 & 0.062 & 0.74 \\
\hline$D O^{f}$ & 3 & 4.82 & 0.049 & 0.71 & 1 & 0.65 & 0.451 & 0.10 & 3 & 1.95 & 0.224 & 0.49 \\
\hline TSS $^{\mathrm{g}}$ & 3 & 2.52 & 0.13 & 0.49 & 1 & 47.65 & $<0.001$ & 0.86 & 3 & 4.52 & 0.039 & 0.63 \\
\hline $\mathrm{pH}$ & 3 & 0.88 & 0.503 & 0.31 & 1 & 15.95 & 0.007 & 0.73 & 3 & 2.39 & 0.167 & 0.55 \\
\hline \multicolumn{13}{|c|}{ 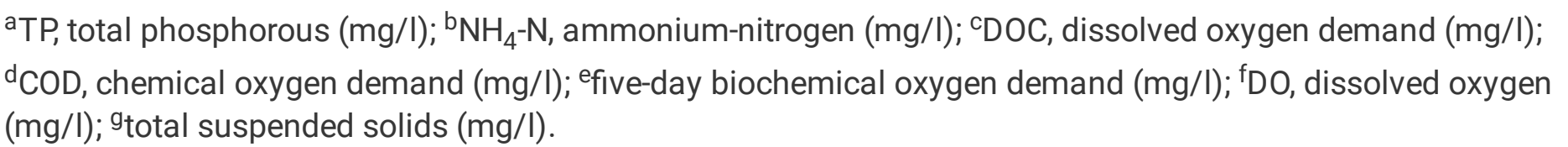 } \\
\hline
\end{tabular}

\section{Discussion}

The concentration of DOC in the unmanaged mesocosms increased along the climate scenario gradient from the coldest (current climate) to the warmest simulated climate (RCP 8.5). Although the impact of the climate scenarios was not found to be significant, there was an increasing trend from the coldest to the warmest climate scenario for most measurements. This suggests that higher temperatures and lower water levels could increase particularly aerobic microbial activity and solubility of some nutrients (Evans et al. 1999, Blodau 2002), accelerating peat mineralization (Gough et al. 2016). This commonly results in an increase in DOC leaching (Eimers et al. 2003; Clark et al. 2007) over time. Menberu et al. (2017) noted that the drawdown of the water table in a boreal-rich fen by only $3 \mathrm{~cm}$ could increase the DOC production by 21.8 percent. The 2018 drought boosted DOC in the unmanaged system over the summer and autumn, when rain washed out the unsaturated and aerated peat, resulting in high DOC concentrations that lasted until the following year.

Our findings are in accordance with those of Ritson et al. (2017) who found that mild droughts can result in an increase of about 40\% DOC production from peat. However, our results contradicted some findings from other studies (Clark et al. 2012; Juckers et al. 2014), which reported a significant decline of DOC in response to the simulated drought. Drought, on the other hand, may have little influence on the amount of DOC produced by vegetation litter. As a result, future concerns should focus on the impact of drought on peat decomposition, 
resulting in a release of recalcitrant DOC, which is difficult to be removed using conventional water treatment methods such as the coagulation and flocculation process (Ritson et al. 2017).

Figure 4 shows the seasonal averages for selected variables under four climate scenarios for the peatland mesocosms over the period of the experiment from 2017 to 2020 . The managed mesocosms in this study had just a slight increase in DOC during the drought of summer 2018, indicating that water level management had a substantial impact, which reduced the concentration of DOC between three- and four-times in the managed mesocosms compared to the unmanaged system during the post-drought period from autumn 2019 until the end of summer 2020) (Fig. 4,f) (Ritson et al. 2017).

The observed increase in DOC concentrations during and after droughts is consistent with previous research (Worrall et al. 2006). Other studies that assessed the impact of rising water levels on DOC release in drained peatlands reported both an increase (Koskinen et al. 2011) and a decrease or no effect (Ramchunder et al. 2009, Armstrong et al. 2010, Wilson et al. 2011).

The $\mathrm{BOD}_{5}$ concentration in the unmanaged mesocosms responded to drought in the warmer climate scenarios (RCP 4.5 and RCP 8.5) earlier than those in the colder climate scenarios. This is due to the fact that, in warmer climate scenarios, higher temperatures for longer periods of time enhance microbial activity. This can result in a faster degradation of peat and vegetation litter and the subsequent release of more biodegradable organic matter in warmer compared to colder climate (Fenner and Freeman 2011). However, under the current climate scenario and RCP 2.6, biodegradable organic matter leached out from the unmanaged mesocosms with a delay during autumn, when temperatures decreased and the mesocosms received more rainwater. No trend was found for $\mathrm{BOD}_{5}$ of the unmanaged mesocosms under different climate scenarios during the growing season of 2020 due to the fact that $\mathrm{BOD}_{5}$ is also controlled by substrate quality in addition to environmental factors. Water level management of the managed mesocosms could significantly reduce the $\mathrm{BOD}_{5}$, and all managed mesocosms in all climate scenarios revealed a decrease between 7 and 17 times over the experimental period (Fig. 4g,h).

The concentration of COD decreased between two and seven times in the managed mesocosms compared to the unmanaged ones as a result of the significant effect of water level management (Fig. 4i,j). These findings are consistent with those of Saarinen et al. (2010) who reported a significant positive correlation between the catchment proportion percentage of a drained peatland and COD concentrations.

According to some findings, prediction of phosphorus response to environmental factors is not straightforward (Vasander et al. 2003; Urbanová et al. 2011); neither water level (Fölster et al. 2014) nor temperature (Munir et al. 2017) change is likely to be a significant driver for phosphorus release. In this study, during spring and summer, the release of phosphorus increased in the unmanaged mesocosms (Fig. 4a), most likely due to their highly readily soluble peat phosphorus concentration as a result of peat decomposition (Kaila et al. 2016). Moreover, managed mesocosms had lower phosphorus concentrations than unmanaged ones (Fig. 4b).

Our findings are in line with what Munir et al. (2017) noted; the higher water levels decrease the phosphorus concentration in the outflow. They, however, observed a significant effect of the water level on phosphorus availability, but this was not the case in this study; although, a decreasing trend of phosphorus concentration was found in this project, too (Fig. 4a,b). Other studies reported decreases (Lundin and Bergquist 1990), increases (Kløve et al. 2010) and no differences (Macrae et al. 2013) in terms of phosphorus with the water level drawdown. These discrepancies could be attributed primarily to the fact that nitrogen and phosphorus are

Page $10 / 22$ 
limiting nutrients in ombrotrophic bogs, which have a high plant productivity (Idol et al. 2007; Iversen et al. 2010). Drawdown of water levels create an aerobic zone, which promotes vascular vegetation expansion and growth (Munir et al. 2014) and their deeper root systems may absorb more phosphorus from the peat (Cleve et al. 1983). As a result, while the production of phosphorus and nitrogen may rise with reduced water levels, plants can consume them at the same or even higher rate.

Warmer climate and lower moisture content, as seen during droughts and especially in warmer climate scenarios, can result in the top soil being well aeration. This is favorable for nitrification and the production of $\mathrm{NO}_{3}$. In our study, measurements of $\mathrm{NO}_{3}$ over the first six months revealed that $\mathrm{NO}_{3}$ has a very low concentration, which was lower than the quality standards for surface freshwater. However, $\mathrm{NH}_{4}-\mathrm{N}$ had a high concentration (Westbrook and Devito 2004). Although our peatland mesocosms had aerobic conditions in their top part, it was expected that nitrification lowers the $\mathrm{NH}_{4}-\mathrm{N}$ concentration, but presumably a low $\mathrm{pH}$ might have restricted nitrification activity (Bridgham et al. 2001), leading to the dominance of $\mathrm{NH}_{4}-\mathrm{N}$ (Wang et al. 2016).

Munir et al. (2017) quantified the nutrient release from a Canadian bog in response to experimental warming and water table lowering. They noted that the $\mathrm{NH}_{4}-\mathrm{N}$ concentration within peat increased with water table depth and time. They also reported that warming treatment alone could not change the $\mathrm{NH}_{4}-\mathrm{N}$ concentration. These results are in line with this study in that sense that the impact of the climate scenario alone was not essential. However, the water level management had a strong effect that could result in a decrease of $\mathrm{NH}_{4}-\mathrm{N}$ concentration between 4 and 50 times in the managed mesocosms compared to the unmanaged ones during the post-drought period between autumn 2019 and the end of summer 2020 (Fig. 4c,d) (Frank et al. 2014; Laine et al. 2013). The decreasing trend of $\mathrm{NH}_{4}-\mathrm{N}$ as a result of water level management validates Lundin et al. (2017) findings indicating that rewetting can have a major impact on lowering the amount of $\mathrm{NH}_{4}-\mathrm{N}$ that lasts for a long time.

Figure 5 shows the seasonal averages for selected parameters under different climate scenarios for the peatland mesocosms under four climate scenarios. Lowering the water tables of peatlands have been shown to increase the load of suspended solids in peatland outflows over the short-term (Fig. 5a) (Ahtiainen and Huttunen 1999). This is of importance as in nature peat particles (as part of TSS) can be transported to water bodies downstream, subsequently fall out of suspension and decompose, potentially causing oxygen depression, which has a negative impact on aquatic life (Glooschenko et al. 1990). Furthermore, the decomposition of organic matter in the aquatic system might lead to an increase in atmospheric carbon dioxide levels (Davidson and Janssens 2006).

In our study, the comparison of managed and unmanaged mesocosms revealed that water level management could reduce the TSS of the mesocosms for all climate scenarios; this effect was statistically significant for all future climate scenarios (Table 1; Fig. 5a,b). The efficiency of water level management was such that it could reduce TSS by between 60 and $90 \%$ in the managed mesocosms over three years (Fig. $5 \mathrm{a}, \mathrm{b}$ ). These findings support the outcomes of Martin-Ortega et al. (2014), who found strong evidence of rapid (less than five years) responses of suspended sediments to peatland re-wetting. While all of the managed mesocosms showed a constant decreasing pattern over time, the unmanaged mesocosm TSS trend was inconsistent among climate scenarios. This is due to the interaction impact of climate change and water level, which appeared to have a significant effect on TSS change over time. As a result of this effect, for colder temperature scenarios, the current climate scenario and RCP 2.6 showed a rising trend, whereas the warmer climate scenarios (RCP 4.5 and 8.5 ) 
were characterized by a declining trend. These results can be attributed to the dilution effect of rain, as the unmanaged mesocosms, which were subjected to warmer climate scenarios, experienced more rain during autumn 2020 than the unmanaged mesocosms that were exposed to colder climate scenarios.

Under all climate scenarios, both managed and unmanaged systems showed an increasing trend in $\mathrm{pH}$ over time (Fig. 3b). However, this increase was greater in the unmanaged system due to increased nutrient and labile carbon levels, which raised the $\mathrm{pH}$ (Fenner and Freeman 2011). In general, a higher pH of the peatland outflow can be expected in the face of climate change. However, this can be slightly lowered by water level management.

\section{Conclusions And Recommendations}

The impacts of current climate and future RCP climate scenarios (RCP 2.6, RCP 4.5 and RCP 8.5) as well as the effects of water level management for each climate scenario were assessed on the water quality of the experimental bog mesocosms over three years. The effect of climate change on the water quality of peatland mesocosms was not significant. However, the impact of water level was found to be strongly significant. Drought had a considerable impact on chemical variables, increasing their concentration and deteriorating the water quality of peatland outflow. The effect of water level management was highest for $\mathrm{NH}_{4}-\mathrm{N}$ and $\mathrm{BOD}_{5}$, and smallest for total phosphorus.

The increases in nutrient concentrations following the drought were long-lasting, and it is possible that it will continue in future years. However, water level management showed a considerable effect on lowering the concentration of all water quality indicators including nutrients to levels up to 50 times.

Most efficient water level management in terms of lowering physiochemical parameter concentrations was found under RCP 8.5. In contrast, management in terms of water level adjustment was least effective under the current climate scenario indicating the necessity of water level management for the warmer climate scenarios.

Our findings highlight the need for water level management in stabilizing nutrient levels in peatland outflows to mitigate the negative consequences of global warming (draught in this study), as any harmful effects are difficult to be reversed. Not only the negative consequences of climate change and drought on peatland can impair the water quality of receiving watercourses, but they can also increase the greenhouse gas emissions from peatland as well as receiving water bodies. Therefore, our findings stress the positive impact of water level management particularly during droughts that can protect ecosystem services such as clean water provision and air purification for peatlands and receiving watercourses at the same time.

\section{Declarations}

Acknowledgements The authors also acknowledge additional funding received by the Division of Water Resources Engineering and the support of many colleagues (including Ronny Berndtsson, Cintia Bertacchi Uvo, Magnus Persson, Per-Olof Rosenkvist, Hossein Hashemi, Erik Nilsson and Anchita Anchita) and international visitors.

Author contributions Miklas Scholz undertook the study conception, design, methodology, funding acquisition, resources and supervision. Material preparation, data collection and formal analysis were performed by 
Shokoufeh Salimi. The first draft of the manuscript was written by Shokoufeh Salimi. Miklas Scholz wrote the final article. Both authors read and approved the final manuscript.

Funding This work was financially supported by VINNOVA (Swedish government innovation agency), RainSolutions (Water JPI 2018 Joint Call project), WATERAGRI (European Union Horizon 2020 research and innovation programme under Grant Agreement Number 858735) and EcoDiver (Naturvårdsverket (Swedish Government Innovation Agency)).

Data availability The data that support the findings of this study are available from the corresponding author upon reasonable request.

Ethics approval and consent to participate Not applicable.

Consent for publication Not applicable.

Competing interests The authors declare no competing interests.

Open Access This article is licensed under a Creative Commons Attribution 4.0 International License, which permits use, sharing, adaptation, distribution and reproduction in any medium or format, as long as you give appropriate credit to the original author(s) and the source, provide a link to the Creative Commons licence, and indicate if changes were made. The images or other third party material in this article are included in the article's Creative Commons licence, unless indicated otherwise in a credit line to the material. If material is not included in the article's Creative Commons licence and your intended use is not permitted by statutory regulation or exceeds the permitted use, you will need to obtain permission directly from the copyright holder. To view a copy of this licence, visit http://creativecommons.org/licenses/by/4.0/

\section{References}

1. Andersen R, Wells C, Macrae M, Price J (2013) Nutrient mineralisation and microbial functional diversity in a restored bog approach natural conditions 10 years post restoration. Soil Biol Biochem. https://doi.org/10.1016/j.soilbio.2013.04.004

2. Armstrong A, Holden J, Kay P, Francis B, Foulger M, Gledhill S et al (2010) The impact of peatland drainblocking on dissolved organic carbon loss and discoloration of water; results from a national survey. J Hydrol. https://doi.org/10.1016/j.jhydrol.2009.11.031

3. Belyea LR, Malmer N (2004) Carbon sequestration in peatland: patterns and mechanisms of response to climate change. Glob Change Biol. https://doi.org/10.1111/j.1529-8817.2003.00783.x

4. Blodau C (2002) Carbon cycling in peatlands A review of processes and controls. Environm Rev https://doi. org/10.1139/a02-004

5. Bragazza L, Parisod J, Buttler A, Bardgett RD (2013) Biogeochemical plant-soil microbe feedback in response to climate warming in peatlands. Nat Clim Change. https://doi.org/10.1038/nclimate1781

6. Bridgham SD, Updegraff K, Pastor J (2001) A comparison of nutrient availability indices along an ombrotrophic-minerotrophic gradient in Minnesota wetlands. Soil Sci Soc Am J. https://doi.org/10.2136/sssaj2001.651259x 
7. Charman DJ, Beilman DW, Blaauw M, Booth RK, Brewer S, Chambers FM et al (2013) Climate-related changes in peatland carbon accumulation during the last millennium. Biogeosciences https://doi.org/10.5194/bg-10-929-2013

8. Clark JM, Ashley D, Wagner M, Chapman PJ, Lane SN, Evans CD, Heathwaite AL (2009) Increased temperature sensitivity of net DOC production from ombrotrophic peat due to water table draw-down. Glob Change Biol. https://doi.org/10.1111/j.1365-2486.2008.01683.x

9. Clark JM, Heinemeyer A, Martin P, Bottrell SH, Biogeochemistry (2012) https://doi.org/10.1007/s10533-0119624-9

10. Clark JM, Lane SN, Chapman PJ, Adamson JK (2007) Export of dissolved organic carbon from an upland peatland during storm events: Implications for flux estimates. J Hydrol.

https://doi.org/10.1016/j.jhydrol.2007.09.030

11. Clymo RS, Turunen J, Tolonen K, Oikos (1998) https://doi.org/10.2307/3547057

12. Davidson EA, Janssens IA (2006) Temperature sensitivity of soil carbon decomposition and feedbacks to climate change. Nature. https://doi.org/10.1038/nature04514

13. Eimers MC, Dillon PJ, Schiff SL, Jeffries DS (2003) The effects of drying and re-wetting and increased temperature on sulphate release from upland and wetland material. Soil Biol Biochem. https://doi.org/10.1016/j.soilbio.2003.08.013

14. Erwin KL (2009) Wetlands and global climate change: the role of wetland restoration in a changing world. Wetl Ecol Managem. https://doi.org/10.1007/s11273-008-9119-1

15. Evans MG, Burt TP, Holden J, Adamson JK (1999) Runoff generation and water table fluctuations in blanket peat: evidence from UK data spanning the dry summer of 1995. J Hydrol. https://doi.org/10.1016/S00221694(99)00085-2

16. Fenner N, Freeman C (2011) Drought-induced carbon loss in peatlands. Nat Geosci. https://doi.org/10.1038/ngeo1323

17. Frank S, Tiemeyer B, Gelbrecht J, Freibauer A (2014) High soil solution carbon and nitrogen concentrations in a drained Atlantic bog are reduced to natural levels by 10 years of rewetting. Biogeosciences https://doi.org/10.5194/bg-11-2309-2014

18. Fölster J, Johnson RK, Futter MN, Wilander A, Ambio (2014) https://doi.org/10.1007/s13280-014-0558-Z

19. Gough R, Holliman PJ, Fenner N, Peacock M, Freeman C (2016) Influence of water table depth on pore water chemistry and trihalomethane formation potential in peatlands. Wat Environm Res.

https://doi.org/10.2175/106143015X14362865227878

20. Grover SPP, Baldock JA (2013) The link between peat hydrology and decomposition: Beyond von Post. J Hydrol. https://doi.org/10.1016/j.jhydrol.2012.11.049

21. Harenda KM, Lamentowicz M, Samson M, Chojnicki BH (2018) The role of peatlands and their carbon storage function in the context of climate change.. In: In: Zielinski T, Sagan I, Surosz W (eds) Interdisciplinary approaches for sustainable development goals. Springer, Cham, pp 169-187. https://doi.org/10.1007/9783-319-71788-3_12

22. Idol T, Baker PJ, Meason D (2007) Indicators of forest ecosystem productivity and nutrient status across precipitation and temperature gradients in Hawaii. J Trop Ecol.

https://doi.org/10.1017/S0266467407004439

Page $14 / 22$ 
23. Iversen CM, Bridgham SD, Kellogg LE, Ecology (2010) https://doi.org/10.1890/09-0064.1

24. Jassey VE, Reczuga MK, Zielińska M, Słowińska S, Robroek BJ, Mariotte P et al (2018) Tipping point in plant-fungal interactions under severe drought causes abrupt rise in peatland ecosystem respiration. Glob Change Biol. https://doi.org/10.1111/gcb.13928

25. Juckers M, Watmough SA (2014) Impacts of simulated drought on pore water chemistry of peatlands. Environm Poll. https://doi.org/10.1016/j.envpol.2013.08.011

26. Kaila A, Asam Z, Koskinen M, Uusitalo R, Smolander A, Kiikkilä O et al (2016) Impact of re-wetting of forestrydrained peatlands on water quality-a laboratory approach assessing the release of $\mathrm{P}, \mathrm{N}, \mathrm{Fe}$, and dissolved organic carbon. Wat Air Soil Pollut. https://doi.org/10.1007/s11270-016-2994-9

27. Kløve B, Sveistrup TE, Hauge A, Geoderma (2010) https://doi.org/10.1016/j.geoderma.2009.08.022

28. Koskinen M, Sallantaus T, Vasander H (2011) Post-restoration development of organic carbon and nutrient leaching from two ecohydrologically different peatland sites. Ecolog Eng.

https://doi.org/10.1016/j.ecoleng.2010.06.036

29. Laine MP, Strömmer R, Arvola L (2013) Nitrogen release in pristine and drained peat profiles in response to water table fluctuations: a mesocosm experiment. Appl Environm Soil Sci.

https://doi.org/10.1155/2013/694368

30. Limpens J, Berendse F, Blodau C, Canadell JG, Freeman C, Holden J, Biogeosciences et al (2008) https://doi.org/10.5194/bg-5-1475-2008

31. Lucchese M, Waddington JM, Poulin M, Pouliot R, Rochefort L, Strack M (2010) Organic matter accumulation in a restored peatland: Evaluating restoration success. Ecol Eng.

https://doi.org/10.1016/j.ecoleng.2009.11.017

32. Lund M, Christensen TR, Lindroth A, Schubert P (2012) Effects of drought conditions on the carbon dioxide dynamics in a temperate peatland. Environm Res Lett. https://doi.org/10.1088/1748-9326/7/4/045704

33. Lundin L, Bergquist B, Hydrobiologia (1990) https://doi.org/10.1007/BF00006108

34. Lundin L, Nilsson T, Jordan S, Lode E, Strömgren M (2017) Impacts of rewetting on peat, hydrology and water chemical composition over 15 years in two finished peat extraction areas in Sweden. Wetl Ecol Managem. https://doi.org/10.1007/s11273-016-9524-9

35. Macrae ML, Devito KJ, Strack M, Waddington JM (2013) Effect of water table drawdown on peatland nutrient dynamics: implications for climate change. Biogeochemistry https://doi.org/10.1007/s10533-0129730-3

36. Macrae ML, Devito KJ, Strack M, Waddington JM (2013) Effect of water table drawdown on peatland nutrient dynamics: implications for climate change. Biogeochemistry https://doi.org/10.1007/s10533-0129730-3

37. Martin-Ortega J, Allott TE, Glenk K, Schaafsma M (2014) Valuing water quality improvements from peatland restoration: Evidence and challenges. Ecosyst Serv. https://doi.org/10.1016/j.ecoser.2014.06.007

38. Menberu MW, Marttila H, Tahvanainen T, Kotiaho JS, Hokkanen R, Kløve B, Ronkanen AK (2017) Changes in pore water quality after peatland restoration: Assessment of a large-scale, replicated before-after-controlimpact study in Finland. Wat Res Res. https://doi.org/10.1002/2017WR020630

39. Moore TR, Roulet NT, Waddington JM (1998) Uncertainty in predicting the effect of climatic change on the carbon cycling of Canadian peatlands. Clim Change. https://doi.org/10.1023/A:1005408719297

Page $15 / 22$ 
40. Munir TM, Khadka B, Xu B, Strack M (2017) Mineral nitrogen and phosphorus pools affected by water table lowering and warming in a boreal forested peatland. Ecohydrology 10. https://doi.org/10.1002/eco.1893

41. Munir TM, Xu B, Perkins M, Strack M, Biogeosciences (2014) https://doi.org/10.5194/bg-11-807-2014

42. Ramchunder SJ, Brown LE, Holden J (2009) Environmental effects of drainage, drain-blocking and prescribed vegetation burning in UK upland peatlands. Progr Physic Geogr.

https://doi.org/10.1177/0309133309105245

43. Ritson JP, Bell M, Brazier RE, Grand-Clement E, Graham NJ, Freeman C et al (2016) Managing peatland vegetation for drinking water treatment. Sci Rep. https://doi.org/10.1038/srep36751

44. Ritson JP, Brazier RE, Graham NJ, Freeman C, Templeton MR, Clark JM (2017) The effect of drought on dissolved organic carbon (DOC) release from peatland soil and vegetation sources. Biogeosciences https://doi.org/10.5194/bg-14-2891-2017, 2017

45. Saarinen T, Vuori KM, Alasaarela E, Kløve B (2010) Long-term trends and variation of acidity, CODMn and colour in coastal rivers of Western Finland in relation to climate and hydrology. Sci Tot Environm. https://doi.org/10.1016/j.scitotenv.2010.07.009

46. Salimi S, Scholz M (2021) Impact of future climate scenarios on peatland and constructed wetland water quality: A mesocosm experiment within climate chambers. J Environm Managem. https://doi.org/10.1016/j.jenvman.2021.112459

47. Salimi S, Almuktar S, Scholz M (2021) The impact of climate change on wetland ecosystems: A critical review of experimental wetland mesocosms. J Environm Managem https://doi.org/10.1016/j.jenvm an.2021.112160

48. Salimi S, Berggren M, Scholz M (2021) Response of the peatland carbon dioxide sink function to future climate change scenarios and water level management. Glob Change Biol. https://doi.org/10.1088/17489326/7/4/045704

49. Strack M, Waddington JM, Bourbonniere RA, Buckton EL, Shaw K, Whittington P, Price JS (2008) Effect of water table drawdown on peatland dissolved organic carbon export and dynamics. Hydrolog Process Int J. https://doi.org/10.1002/hyp.6931

50. Tiemeyer B, Frings J, Kahle P, Köhne S, Lennartz B (2007) A comprehensive study of nutrient losses, soil properties and groundwater concentrations in a degraded peatland used as an intensive meadowimplications for re-wetting. J Hydrol. https://doi.org/10.1016/j.jhydrol.2007.08.002

51. Turetsky MR (2003) The role of bryophytes in carbon and nitrogen cycling. Bryologist https://. doi: $10.1639 / 05$

52. Tuukkanen T, Marttila H, Kløve B (2017) Predicting organic matter, nitrogen, and phosphorus concentrations in runoff from peat extraction sites using partial least squares regression. Wat Res Res.

https://doi.org/10.1002/2017WR020557

53. Urbanová Z, Picek T, Bárta J (2011) Effect of peat re-wetting on carbon and nutrient fluxes, greenhouse gas production and diversity of methanogenic archaeal community. Ecol Eng.

https://doi.org/10.1016/j.ecoleng.2010.07.012

54. Urbanová Z, Picek T, Bárta J (2011) Effect of peat re-wetting on carbon and nutrient fluxes, greenhouse gas production and diversity of methanogenic archaeal community. Ecol Eng.

https://doi.org/10.1016/j.ecoleng.2010.07.012

Page $16 / 22$ 
55. Vasander H, Tuittila ES, Lode E, Lundin L, llomets M, Sallantaus T et al (2003) Status and restoration of peatlands in northern Europe. Wetl Ecol Managem. https://doi.org/10.1023/A:1022061622602

56. Waddington JM, Morris PJ, Kettridge N, Granath G, Thompson DK, Moore PA (2015) Hydrological feedbacks in northern peatlands. Ecohydrology https://doi.org/10.1002/eco.1493

57. Wang H, Richardson CJ, Ho M, Flanagan N (2016) Drained coastal peatlands: A potential nitrogen source to marine ecosystems under prolonged drought and heavy storm events-A microcosm experiment. Sci Tot Environm. https://doi.org/10.1016/j.scitotenv.2016.04.211

58. Westbrook CJ, Devito KJ (2004) Gross nitrogen transformations in soils from uncut and cut boreal upland and peatland coniferous forest stands. Biogeochemistry https://doi.org/10.1023/B:BIOG.0000025739.04821.8e

59. Westman CJ, Laiho R, Biogeochemistry (2003) https://doi.org/10.1023/A:1023348806857

60. Wilson L, Wilson J, Holden J, Johnstone I, Armstrong A, Morris M (2011) Ditch blocking, water chemistry and organic carbon flux: evidence that blanket bog restoration reduces erosion and fluvial carbon loss. Sci Tot Environm. http://dx.doi.org/10.1016/j.scitotenv.2011.02.036

61. Worrall F, Burt TP, Adamson JK (2006) Trends in drought frequency-the fate of DOC export from British peatlands. Clim Change. https://doi.org/10.1007/s10584-006-9069-7

\section{Figures}

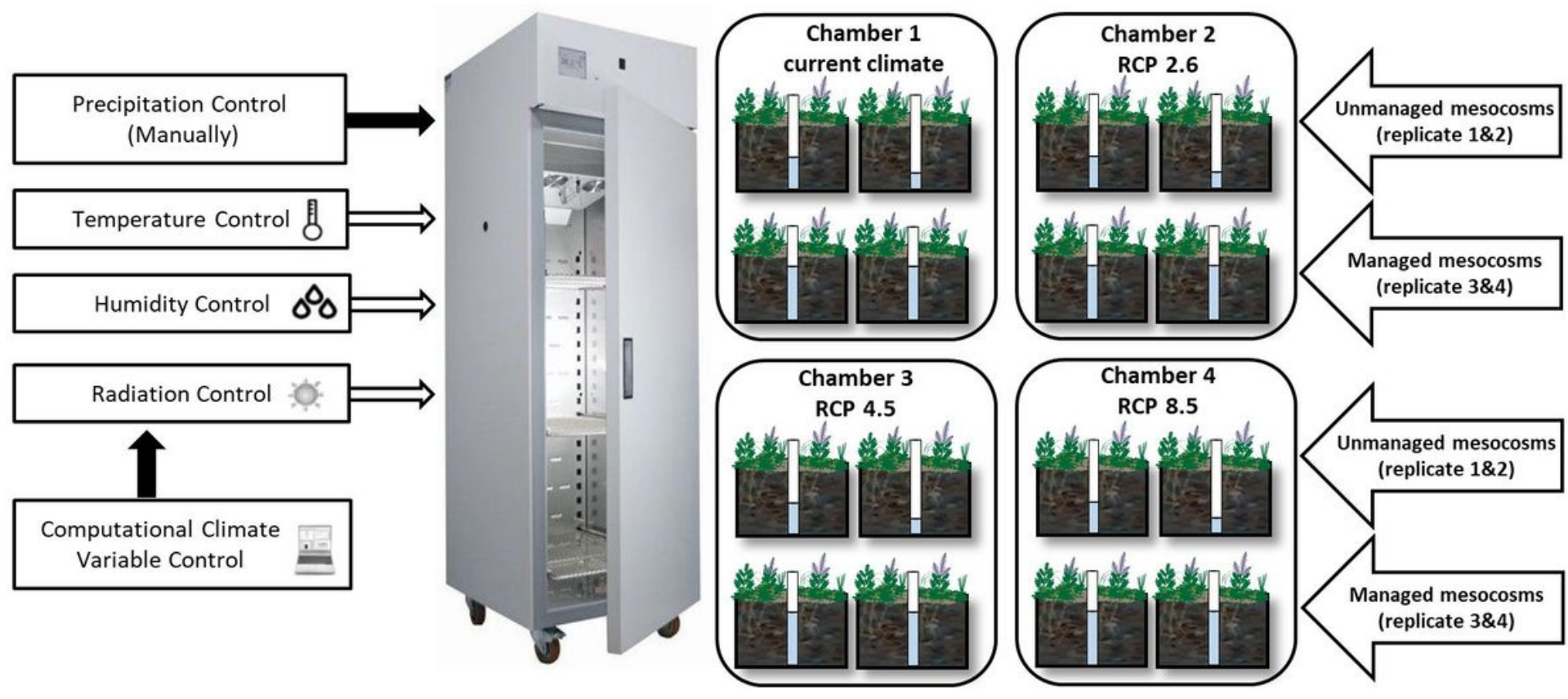

\section{Figure 1}

Design of mesocosm experiment in climate control chambers simulating the current and future representative concentration pathway (RCP) climate scenarios for peatlands 

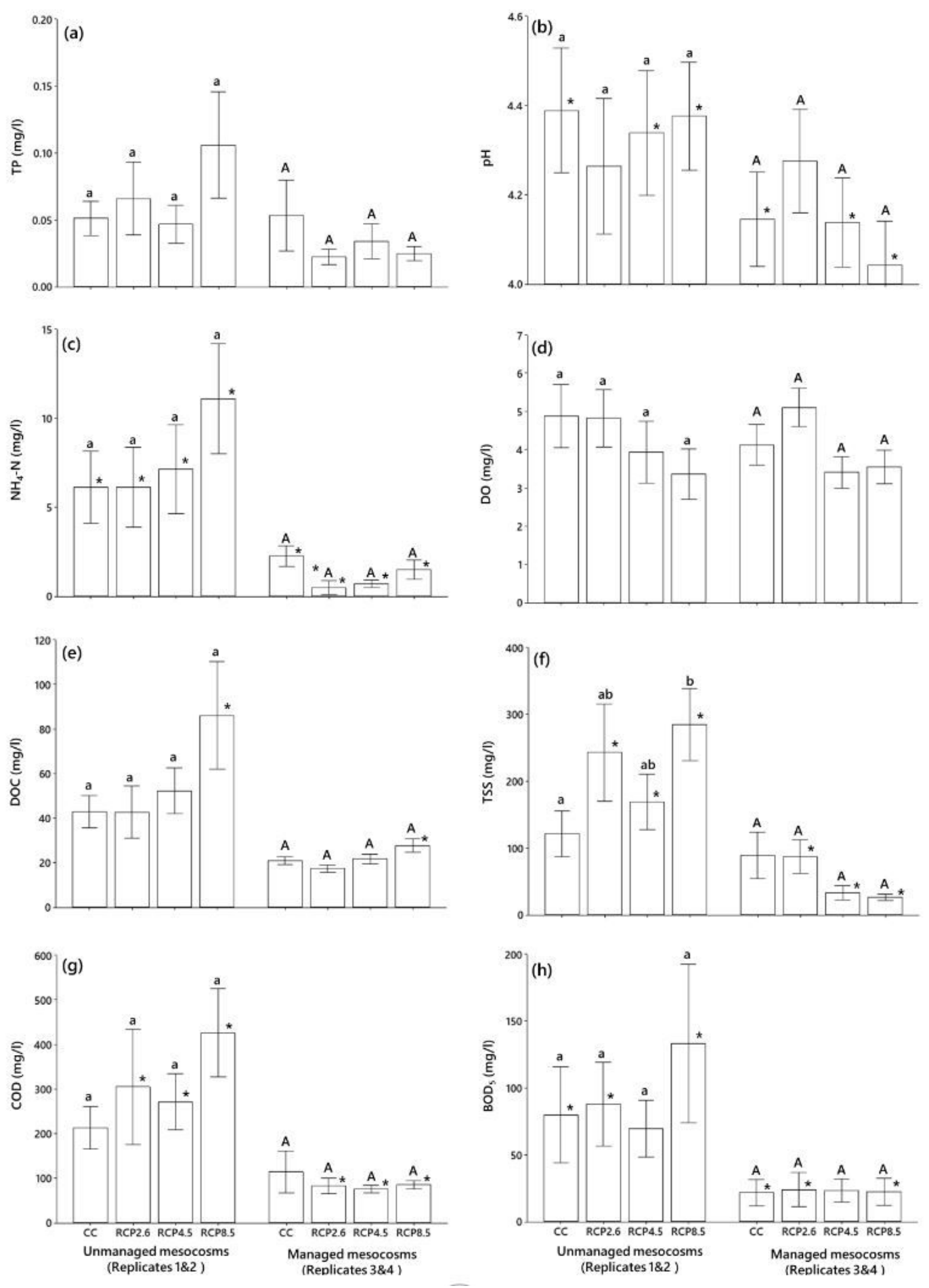

Figure 2

Two-year average (period 2019-2020 of the experiment simulating 2018-2019 in real time) of (a) total phosphorus (TP); (b) pH; (c) ammonium-nitrogen $\left(\mathrm{NH}_{4}-\mathrm{N}\right)$; (d) dissolved oxygen (DO); (e) dissolved organic carbon (DOC); (f) total suspended solids (TSS); (g) chemical oxygen demand (COD); and (h) five-day biochemical oxygen demand $\left(\mathrm{BOD}_{5}\right)$. Asterisks denote significant differences between the unmanaged (replicates 1 and 2 ) and managed (replicates 3 and 4) peatland mesocosms for each climate scenario. Significant differences in climate scenarios have been demonstrated using lower case letters for the unmanaged peatland mesocosms and upper case letters for the managed ones. Means that share the same letter or letters are not significantly different. The significance test is based on a pairwise comparison (Bonferroni adjusted significance test) 


\section{Image not available with this version}

\section{Figure 3}

Trends of (a) total phosphorus (TP); (b) pH; (c) ammonium-nitrogen $\left(\mathrm{NH}_{4}-\mathrm{N}\right)$; (d) dissolved oxygen (DO); (e) dissolved organic carbon (DOC); (f) total suspended solids (TSS); (g) chemical oxygen demand (COD); (h) fiveday biochemical oxygen demand $\left(\mathrm{BOD}_{5}\right)$; (i) temperature; and (j) water level for peatland mesocosms (replicates 1 and 2 as well as replicates 3 and 4) under different climate scenarios (current climate (CC) and future representative concentration pathway (RCP) climate scenarios (RCP 2.6, RCP 4.5 and RCP 8.5) over a three-year experimental period (2017-2020) simulating the real time for the period 2016-2019. Note: During the first year of the experiment, all peatland mesocosms (replicates 1, 2, 3 and 4) were subject to water level management (2017-2018). In the second and third years of the experiment, replicates 1 and 2 were not managed, but replicates 3 and 4 were managed in terms of water level adjustment 

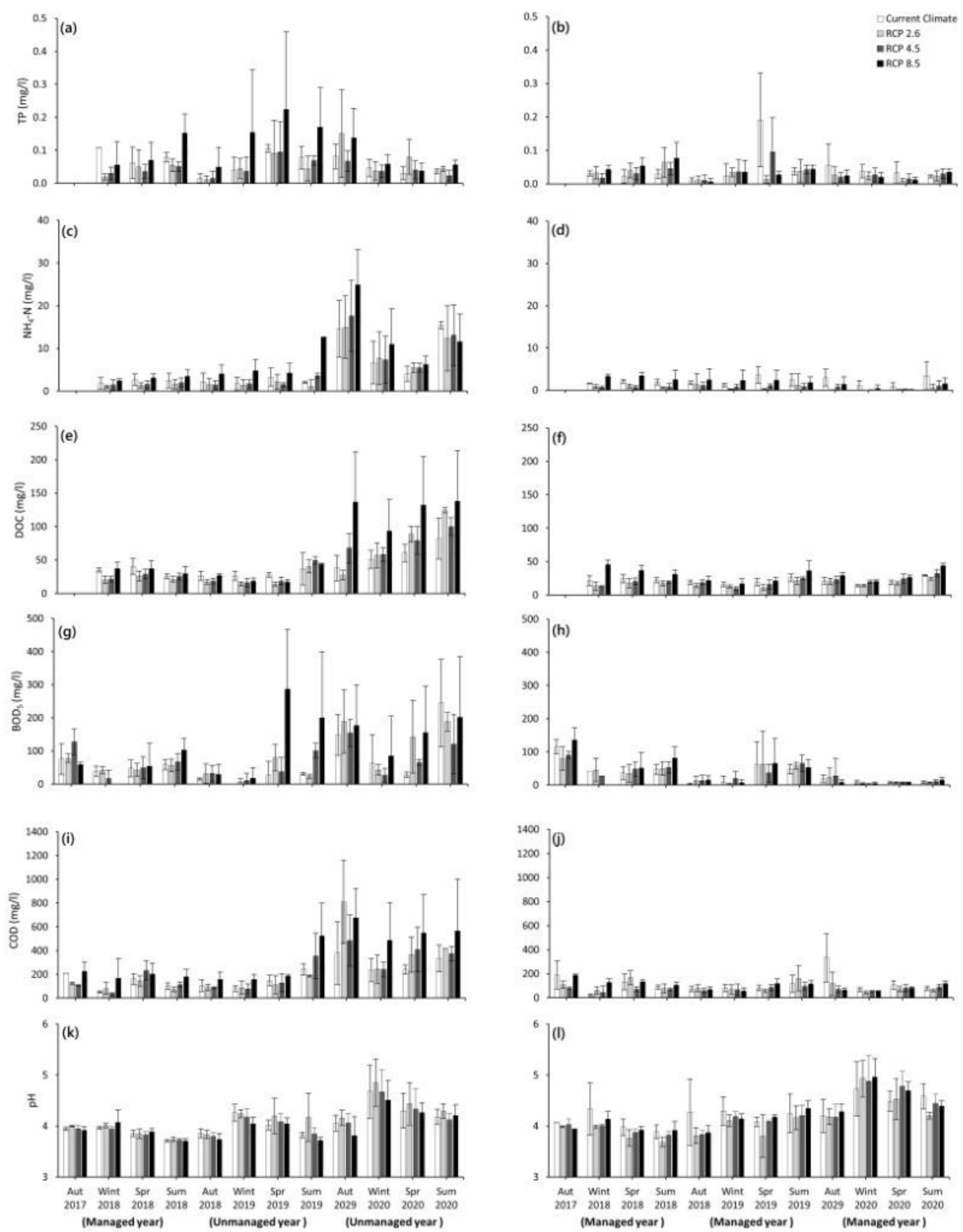

Figure 4

Seasonal averages for (a) total phosphorus (TP) regarding replicates 1 and 2; (b) TP concerning replicates 3 and 4; (c) ammonium-nitrogen $\left(\mathrm{NH}_{4}-\mathrm{N}\right)$ regarding replicates 1 and 2); (d) NH4-N concerning replicates 3 and 4; (e) dissolved organic carbon (DOC) regarding replicates 1 and 2; (f) DOC concerning replicates 3 and 4; (g) five-day biochemical oxygen demand $\left(\mathrm{BOD}_{5}\right)$ regarding replicates 1 and 2; (h) BOD 5 concerning replicates 3 and 4; (i) chemical oxygen demand (COD) regarding replicates 1 and 2; $(j)$ COD concerning replicates 3 and 4; (k) pH regarding replicates 1 and 2; and (I) $\mathrm{pH}$ concerning replicates 3 and 4 under four climate scenarios (current climate (CC) and future RCP (representative concentration pathways) climate scenarios (RCP 2.6, RCP 4.5 and 
RCP 8.5)) for the peatland mesocosms over the period of the experiment from 2017 to 2020 (equivalent to real time between 2016 and 2019)
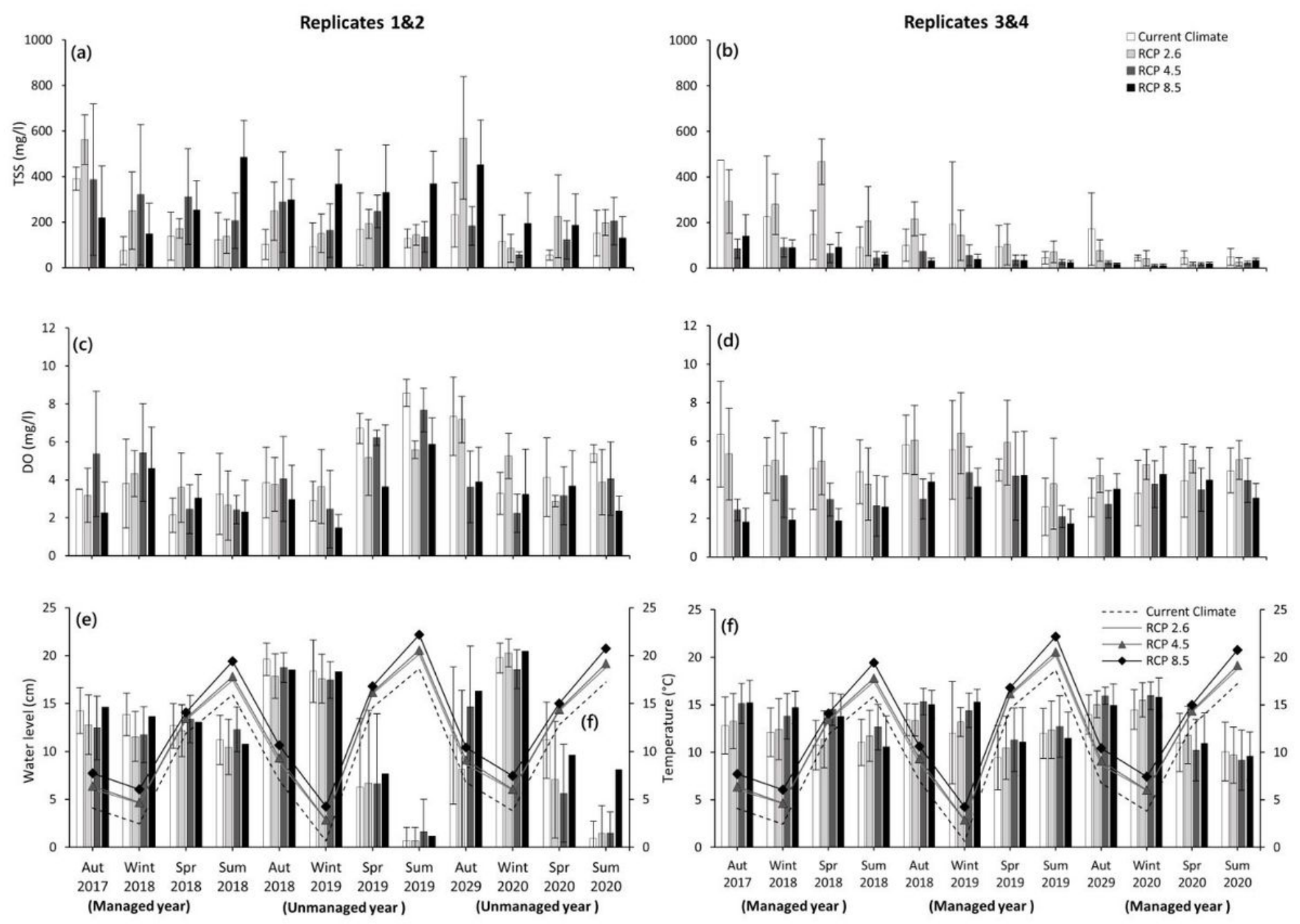

\section{Figure 5}

Seasonal averages for (a) total suspended solids (TSS) regarding replicates 1 and 2; (b) TSS concerning replicates 3 and 4; (c) dissolved oxygen (DO) regarding replicates1 and 2; (d) DO concerning replicates 3 and 4; (e) water level; and (f) temperature under different climate scenarios for the peatland mesocosms under four climate scenarios (current climate (CC) and future representative concentration pathways (RCP) climate scenarios (RCP 2.6, RCP 4.5 and RCP 8.5)) for the peatland mesocosms over the period of the experiment from 2017 to 2020 (equivalent to real time between 2016 and 2019)

\section{Supplementary Files}

This is a list of supplementary files associated with this preprint. Click to download.

- ESPRfigESM1scholz201221.pdf

- ESPRfigESM2scholz201221.pdf 
- ESPRtableESM1scholz201221.pdf 